DOI: https://doi.org/10.24127/ajpm.v8i1.1767

\title{
PENGGUNAAN MODEL ELPSA DENGAN BANTUAN ALAT PERAGA GEOBOARD PADA MATERI BANGUN DATAR SEGIEMPAT
}

\author{
Lilik Firdayati \\ SMP Negeri 3 Metro Lampung \\ E-mail:firdayatililik@gmail.com
}

Received 14 January 2019; Received in revised form 24 March 2019; Accepted 10 May 2019

\begin{abstract}
In fact, most of studens thought that Mathematics is difficult, because the instruction was dull, teacher was less active as facilitator in instruction, teacher did not apply imstructional media, teacher didnot involve students enough in instruction, too many formula but less in practice and also teacher did not maximalized instructional model, as the result, the instruction was ineffective, besides teacher was focuse more on cognotive oriented domain at class instruction, he left students' affective and pshycomotor domains, so that, their maturnity was less maximal. The objective of study wad to improve students' activities and the mathematics'score through geoboard instructional aid. The research was done at seventh hrade of SMP N 3 Metro Lampung on April 2018. It was a Classroom Action Research. Data collection were observation sheets, tes and questionnaire that was students' response to instruction. It was analysed through descriptive analytic technique. The result of study was the using of ELPSA model through geoboard assisstance at two dimentional figure could improve the avetage value $55.36 \%$ at cycle I into $74.49 \%$ at cycle $l l$, and the average result value was 55.06 at cycle ll became 67.41 at cycle ll. Based on the data finding, it can be infered that in appliying mathematis at class teacher should motivate students' interest and also fix the quality of instruction through variation of instructional model and suitable teaching aid,so that students' result can be maximazed
\end{abstract}

Keywords: ELPSA model; geoboard props.

\section{PENDAHULUAN}

Matematika merupakan salah satu pelajaran yang penting dan digunakan dihampir semua bidang. Hal ini dikarenakan Matematika masih tetap digunakan dalam banyak hal. Dalam tingkatan pendidikan dasar sampai perguruan tinggi, pelajaran Matematika masih dipelajari. Namun, banyak kendala yang dianggap sulit oleh para siswa dalam mempelajari Matematika. Berkaitan dengan hal tersebut, berdasarkan survei awal hasil ujian tengah semester dari 28 orang siswa kelas VIIA SMP Negeri 3 Metro, Lampung sebagai subyek penelitian menunjukkan nilai rata-rata Matematika masih rendah yaitu 57,70 dengan Kriteria Ketuntasan 60, dan 14 siswa memperoleh nilai di bawah KKM. Beberapa siswa menganggap
Matematika itu sulit, karena pembelajarannya kurang menarik, guru kurang berperan sebagai fasilitator, guru tidak menggunakan alat peraga atau media pembelajaran, guru kurang melibatkan siswa secara aktif dalam pembelajaran, banyak rumus, kurang banyak latihan, dan lain-lain. Seperti yang diutarakan oleh (Ismah, 2016) bahwa pembelajaran matematika konvensional dirasa sudah tidak mampu meningkatkan pemahaman konsep matematika siswa dikarenakan sifat abstrak yang dimiliki matematika membuat siswa merasa kesulitan dalam menangkap konsep matematika. Berdasarkan karakteristik yang dimiliki matematika, dibutuhkan pembelajaran yang efektif yang mampu menjelaskan sifat abstrak dari matematika. 
Proses pembelajaran dengan tidak melibatkan aktivitas siswa akan berakibat pada tidak optimalnya pemusatan perhatian pada kemampuan yang harus dikuasainya, siswa sering berada dalam situasi tertekan. Siswa tidak mendapat kesempatan untuk melakukan eksplorasi lingkungan sekitar, sehingga membuat mereka terasing dengan lingkungannya, tidak memiliki kemampuan untuk mencari dan menemukan informasi yang diperlukannya, dan siswa hanya terfokus pada pengembangan ranah kognitif saja dan kurang memperhatikan aspek afeksi (emosional, mental, keterampilan, dan spiritual). Padahal, kondisi pembelajaran seperti itu akan sulit diharapkan untuk mampu membuat siswa memiliki kemampuan berpikir kritis, kreatif, dan inovatif, serta memiliki karakter dan watak untuk menghadapi berbagai permasalahan dalam kehidupannya sehari-hari.

Dari kondisi tersebut menunjukkan guru merupakan salah satu faktor yang dominan penyebab kesulitan belajar siswa. Selama ini, guru mendominasi pembelajaran dengan ceramah dan tidak melibatkan siswa secara aktif dalam pembelajaran. Guru jarang menggunakan media pembelajaran interaktif dan menarik. Akibatnya siswa pasif karena tidak diberi kesempatan untuk berpikir dan menemukan konsep sendiri. Pembelajaran sangat membosankan dan tidak efektif, dan berdampak pada rendahnya hasil belajar Matematika.

Di dalam Kurikulum 2013 setiap pembelajarannya siswa dituntut untuk aktif, kreatif dan inovatif, serta kemampuan berpikir siswa dalam mempelajari setiap konsep mata pelajaran harus berkembang sesuai dengan umur dan karakter siswa.Dalam mengembangkan kemampuan matematis siswa, pembelajaran harus menjadi lingkungan dimana siswa mampu terlibat secara aktif dalam kegiatan yang bermanfaat. Siswa harus aktif dalam belajar, tidak hanya menyalin atau mengikuti contoh-contoh tanpa tahu maknanya (Effendi, 2012). Menyikapi hal tersebut dalam pembelajaran Matematika perlu dimunculkan ide-ide kreatif dan inovatif untuk meningkatkan kemampuan berpikir dan kreativitas dengan pembelajaran dengan bantuanmedia pembelajaran yang nantinya akan berdampak pada hasil pembelajaran. Banyak alat peraga yang dapat dimanfaatkan untuk mendukung pembelajaran, salah satunya adalah alat peraga geoboard (papan berpaku).

Alat peraga geoboard memiliki pengaruh terhadap hasil belajar siswa pada mata pelajaran matematika (Imas, 2017). Hal ini menunjukkan bahwa dengan penggunaan alat peraga geoboard lebih efektif dalam meningkatkan hasil belajar siswa

Penggunaan media geoboard dilakukan untuk membantu siswa di dalam memahami konsep matematika yang abstrak, sehingga mereka lebih tertarik, merasa lebih tertantang, dan merasa ikut andil di dalam proses pembelajaran dan menemukan konsep. Siswa akan lebih tertarik mempelajari geometri apabila mereka terlibat secara aktif baik individual atau kelompok, mereka hendaknya diberi kesempatan untuk melakukan investigasi yang akan memberikan pemahaman bagi siswa karena diperlukan bimbingan dan arahan dari guru dalam penggunaan media tersebut sehingga dapat mencapai tujuan pembelajaran yang diharapkan pada materi segiempat, dapat meningkatkan pemahaman konsep segiempat siswa.

Penggunaan alat peraga dalam proses pembelajaran bukan merupakan fungsi tambahan tetapi mempunyai fungsi tersendiri sebagai alat bantu untuk mewujudkan situasi pembelajaran yang 
efektif, merupakan bagian yang integral dari keseluruhan situasi mengajar, tujuan dan isi pelajaran, untuk mempercepat proses belajar mengajar dan membantu siswa dalam menangkap pengertian yang diberikan guru, serta diutamakan untuk mempertinggi mutu belajar mengajar (Hartati, 2010).

Media pembelajaran membawa dan membangkitkan rasa senang dan gembira bagi siswa-siswa dan memperbarui semangat mereka, membantu memantapkan pengetahuan pada benak para siswa serta menghidupkan pelajaran (Arsyad, 2011). Tetapi walaupun media menempati kedudukan yang sangat penting sebagai salah satu sumber belajar, media tidak bisa menggantikan peran guru sepenuhnya, artinya media dalam pembelajaran tanpa adanya guru adalah hal yang mustahil dapat meningkatkan kualitas pembelajaran. Karena dalam hal ini gurulah yang bertugas memberikan bimbingan kepada siswa tentang apa yang harus dipelajarinya dan bagaimana siswa mempelajari materi dari media yang ada

Pembelajaran aktif adalah pembelajaran yang harus menumbuhkan suasana sedemikian rupa sehingga peserta didik aktif bertanya, mempertanyakan, dan mengemukakan gagasan (Suprijono, 2010). Belajar merupakan proses aktif dari siswa dalam membangun pengetahuannya. Pembelajaran aktif adalah proses belajar yang menumbuhkan dinamika belajar bagi siswa.

$\begin{array}{rrr}\text { Pada } & \text { proses } & \text { pembelajaran } \\ \text { sebelumnya } & \text { telah } & \text { dilakukan }\end{array}$
pembelajaran matematika yang inovatif tanpa alat peraga yang dapat langsung diperagakan oleh siswa dan pelaksanaan pembelajarannya masih terbatas pada penggunaan model pembelajaran kooperatif dan melalui gambar. Pembelajaran kooperatif dengan Student
Team Achievement Divisions (STAD)dan hanya mengerjakan latihan-latihan soal setelah materi disampaikan.

Berdasarkan refleksi dan evaluasi, pembelajaran Matematika yang telah dilakukan ternyata menjadi kurang menarik jika terlalu sering dilakukan dan tanpa bantuan media atau alat peraga. Penulis memahami dan menyadari bahwa pelaksanaan pembelajaran Matematika yang dilakukan jangan hanya terpaku dengan satu model pembelajaran tertentu saja. Siswa akan merasa jenuh, bosan dengan model pembelajaran yang tidak bervariasi juga media atau alat peraganya, yang akan berakibat siswa kurang dapat membangun kemampuan berpikir matematik. Untuk itu, perlu dilaksanakan variasi pembelajaran dengan bantuan alat peraga geoboard dan menggunakan model pembelajaran ELPSA (Experiences, Language, Pictures, Symbols, Applicatioan)agar dapat menghilangkan kejenuhan dan dapat meningkatkan aktivitas belajar pada siswa.

Beperapa upaya untuk memperbaiki dan meningkatkan keterlibatan atau keaktifan siswa dalam pembelajaran,yaitu: 1) mengenali dan membantu siswa yang kurang terlibat, 2) menyiapkan siswa secara tepat, 3) menyesuaikan pengajaran dengan kebutuhan-kebutuhan individual siswa. Aktivitas siswa dalam proses pembelajaran merupakan salah satu indikator adanya kegiatan siswa untuk belajar (Supinah, 2015). Kegiatankegiatannya adalah yang mengarahkan pada proses belajar seperti bertanya, mengajukan pendapat, mengerjakan tugas-tugas, dapat menjawab pertanyaan guru dan bisa bekerja sama dengan siswa lain, serta tanggung jawab terhadap tugas yang diberikan.

Model Pembelajaran ELPSA yang dikembangkan oleh tim RIPPLE 
(Research Institute for Professional Practice, Learning \& Education) yang diketuai oleh Prof Tom Lowrie dari Charles Sturt University Australia. ELPSA merupakan sebuah kerangka desain pembelajaran yang dibuat secara khusus untuk konteks Indonesia sebagai hasil dari analisis data video TIMSS (Wijaya, 2014).

Kerangka ELPSA dimulai dari menghubungkan pengalaman siswa sebelumnya ke pembelajaran baru, memberi siswa kesempatan untuk mengekspresikan temuan mereka sendiri, dan membangun visual, memikirkan siswa untuk presentasi ide menggunakan simbol, sehingga siswa bisa menganggap matematika sebagai subjek yang bermakna daripada yang sulit (Johar, 2016).

Dalam upaya untuk membelajarkan siswa secara efektif, kerangka kerja ELPSA adalah alat yang praktis dan mudah dipahami untuk merancang suatu pembelajaran Matematika dalam mengembangkan konsep secara bermakna dan eksplisit, meningkatkan kualitas pembelajaran, dan siswa dapat memahami Matematika lebih komprehensif (Patahudin, 2015).

Kerangka kerja ELPSA memiliki janji besar dalam meningkatkan kualitas pembelajaran di ruang kelas Matematika, karena setiap komponen membangun pemahaman dan pemahaman Matematika di kelas, desain pembelajaran akan bekerja paling efektif ketika guru di kelas merangkul logika, menghadirkan kesempatan dan kegiatan pembelajaran dengan cara yang menekankan setiap komponen, sebagai nilai tambah desain melalui pengembangan ide dan praktik matematis yang eksplisit (Patahudin T. L., 2015).

Penerapan kerangka pembelajaran ELPSA selama proses pembelajaran matematika di kelas sangat membantu dalam meningkatkan minat belajar siswa yaitu dengan melibatkan pengalaman belajar siswa (experience), bahasa siswa (language), dan penjelasan yang representatif dalam melibatkan penalaran siswa (pictorial) untuk memahami konten Matematika (Dwijopitoyo, 2017).

STAD merupakan salah satu model pembelajaran kooperatif yang paling sederhana, dan terdiri dari lima komponen utama yaitu presentasi kelas, tim, kuis, skor kemajuan individual dan rekognisi tim. Inti dari STAD adalah guru menyampaikan suatu materi, sementara para siswa tergabung dalam kelompoknya yang terdiri atas 4 atau 5 orang untuk menyelesaikan soal-soal yang diberikan oleh guru. Selanjutnya, siswa diberi kuis/tes secara individual. Skor hasil kuis/tes tersebut disamping untuk menentukan skor individu juga digunakan untuk menentukan skor kelompoknya (Laila, 2010).

Dalam Penelitian lain, bahwa kerangka kerja ELPSA menggambarkan bahwa dalam proses pembelajaran guru menggunakan strategi dan metode yang secara sistematis yang telah dirancang sedemikian rupa sehingga menciptakan suasana pembelajaran yang efektif dan kondusif. Dengan terciptanya proses pembelajaran yang efektif dan kondusif tersebut terlihat bahwa adanya aktivitas serta partisipasi dari siswa yang mengikuti proses pembelajaran. Aktivitas dan partisipasi yang ditunjukkan oleh sebagian dari siswa mampu menjawab pertanyaanpertanyaan yang dilontarkan oleh guru ketika menjelaskan materi pembelajaran, siswa mampu mengungkapkan pendapat melalui pengalaman belajarnya, mampu mengilustrasikan melalui gambar dan memahami dengan benar simbol-simbol matematika yang dipelajari serta dapat 
mengaplikasikannya kepada orang lain. (Ikasari, 2017).

Selain itu, pembelajaran Matematika yang selama ini penulis lakukan tidak banyak memberikan kesempatan kepada siswa untuk meningkatkan kemampuan berpikir dalam meningkatkan kompetensinya sesuai dengan tuntutan dalam pembelajaran. Hal tersebut sebagai akibat dari pembelajaran yang tidak bermakna, siswa hanya diberi rumus tanpa dijelaskan mengapa rumus itu digunakan. Pola pembelajaran semacam ini membuat siswa tidak memahami materi yang diajarkan sehingga berakibat pada rendahnya hasil belajar. Oleh karena itu,diperlukan pembelajaran yang menarik sehingga siswa dapat memperoleh pemahaman tidak hanya menghafal rumus. Pembelajaran memiliki proses yang berkesinambungan untuk mencapai tujuan pembelajaran yang disebut aktivitas belajar. Aktivitas belajar yang berlangsung dalam proses pembelajaran akan berpengaruh dengan hasil belajar.

Hasil belajar sering dijadikan tolok ukur dalam penilaian prestasi akademik dan merupakan cerminan dari kemampuan yang dimiliki siswa selama proses pembelajaran juga salah satu indikator tercapainya tujuan pembelajaran (Widiyasari, 2017). Sebagai alternatif menjawab tantangan tersebut penulis telah berupaya menciptakan pembelajaran yang menarik dengan model pembelajaran ELPSA dan alat peraga geoboard. Kemudian penulis terdorong untuk melakukan sebuah penelitian tentang: "Penggunaan model Pembelajaran ELPSA dengan bantuanalat peraga geoboard pada materi bangun datar segiempat"

Berdasarkan latar belakang masalah tersebut, maka tujuan penelitian tindakan kelas ini adalah: 1) meningkatkan aktivitas belajar siswa dengan model pembelajaran ELPSA dengan bantuan alat peraga geoboard pada materi segiempat. 2) meningkatkan hasil belajar siswa dengan model pembelajaran ELPSA dengan bantuan alat peraga geoboard pada materi segiempat.

Adapun hipotesis tindakan yang diajukan dalam penelitian ini adalah Jika proses pembelajaran dengan model ELPSA menggunakan alat peraga geoboard dapat dilaksanakan sesuai dengan ketentuan juga sesuai dengan kondisi siswa, maka dapat meningkatkan aktivitas dan hasil belajar matematika pada materi bangun datar segiempat.

\section{METODE PENELITIAN}

Penelitian tindakan kelas ini menggunakan model ELPSA dengan bantuan alat peraga geoboard, dilaksanakan di kelas VII A SMP Negeri 3 Metro, Lampung yang berjumlah 28 orang yang terdiri dari laki-laki 13 orang dan perempuan 15 orang. Penelitian dilaksanakan bulan April 2018, mulai tahap persiapan (membuat alat peraga, menyusun RPP, menyusun instrumen) sampai tahap pelaksanaan pembelajaran pada materi bangun datar segiempat, dan tahap penyusunan pelaporan. Dalam penelitian ini dibantu teman sejawat sebagai observer.

Teknik pengumpulan data menggunakan : a. angket (respons siswa dalam pelaksanaan pembelajaran), $b$. observasi (aktivitas siswa selama pembelajaran), dan c. tes (hasil belajar). Data penelitian terdiri dari data kualitatif (hasil pengamatan/observasi) selama pembelajaran dan data kuantitatif yaitu hasil tes belajar bangun datar segiempat dengan sumber data diperoleh langsung dari siswa saat proses pembelajaran.

Analisis data dalam penelitian ini menggunakan teknik deskriptif analitik. Data kualitatif dideskripsikan dan 
ditransformasi secara kuantitatif dengan menentukan persentase masing-masing pengamatan. Analisis data dilakukan pada setiap data yang dikumpulkan, baik data kuantitatif maupun data kualitatif(Astuti, 2011). Berdasarkan jenis data, teknik analisis yang digunakan dideskripsikan,yaitu: 1) data kuantitatif misalnya nilai hasil belajar siswa dapat dianalisis secara statistik deskriptif sederhana, yakni dengan rerata (mean), dan persentase (\%); 2) data kualitatif yaitu data yang berupa informasi berbentuk kalimat yang memberi gambaran tentang ekspresi siswa terhadap tingkat pemahaman suatu mata pelajaran (kognitif), aktivitas atau sikap siswa terhadap penggunaan model pembelajaran ELPSA dan alat peraga geoboard (afektif),

Data kuantitatif hasil belajar ditabulasi dan dihitung ketuntasannya pada masing-masing siklus. Data tersebut dianalisis untuk keberhasilan pembelajaran yang diterapkan dengan indikator meningkatnya hasil belajar siswa baik aspek afektif (keaktifan siswa) maupun aspek kognitif berupa peningkatan aktivitas dan hasil belajar antar siklus dan persentase siswa yang tuntas belajar atau memperoleh nilai $>$ KKM (Kriteria Ketuntasan Minimal) yaitu 60.

\section{HASIL PENELITIAN DAN PEMBAHASAN}

Aktivitas siswa dalam proses pembelajaran, mencakup tujuh indikator, yaitu mengajukan pertanyaan pada guru, menjawab pertanyaan dari guru, mengerjakan LKS yang diberikan, bekerja sama dengan teman satu kelompok, bertukar pendapat antar teman satu kelompok, membuat kesimpulan hasil diskusi, mempresentasikan hasil diskusi.
Model ELPSA dikembangkan berdasarkan pada teori-teori pembelajaran konstruktivisme dan sifatnya sosial. Model ini memandang bahwa pembelajaran sebagai suatu proses aktif dimana para siswa menemukan sendiri cara dalam memahami sesuatu melalui proses pemikiran individu dan interaksi sosial dengan temannya. Adapun penerapan model ELPSA di dalam pembelajaran,yaitu:1) experiences (pengalaman): menghubungkan materi bangun datar segiempat dengan pengalaman siswa dalam kehidupan sehari-hari dan dalam lingkungan sekitar, dengan cara mengidentifikasi jenis-jenisnya dan sifat-sifatnya; 2) language (bahasa): mengenal istilahistilah matematika yang berkaitan dengan bangun datar segiempat, misalnya sisi, sudut, bidang, diagonal, kemudian mendeskripsikan masingmasing bangun datar dengan terminologi matematika, serta membiasakan siswa untuk bertanya; 3) picture (gambar): mengenalkan gambar bangun datar segiempat, kemudian menyiapkan bangun-bangun datar segiempat dari peraga plastik, mengenalkan bentukbentuk bangun datar menggunakan geoboard dan karet gelang; 4) symbol (simbol): memberikan nama bangun datar segiempat dengan simbol ABCD, EFGH dan lai sebagainya; 5) application (aplikasi): mengaplikasikan bangunbangun datar segiempat dengan cara mengelompokkan yang sejenis, menerapkan dalam kehidupan seharihari.

Hal terpenting sebagai dasar dalam mendesain sebuah pembelajaran ELPSA yang bermutu adalah penekanan pembelajaran yang mampu menjadikan siswa memahami konsep secara maksimal melalui simbol meskipun membutuhkan waktu yang relatif lama. 
Alat peraga dibuat berdasarkan prinsip bahwa pengetahuan yang ada pada setiap manusia itu diterima atau ditangkap melalui pancaindra. Semakin banyak indra yang digunakan untuk menerima sesuatu, maka semakin banyak dan semakin jelas pengetahuan yang diperoleh. Alat peraga dimaksudkan untuk mengerahkan indra sebanyak mungkin kepada suatu obyek sehingga mempermudah persepsi.

Berdasarkan pendapat Bruner, bahwa pembelajaran sebaiknya dimulai dengan menggunakan benda nyata terlebih dahulu, oleh karena itu ketika proses pembelajaran matematika berlangsung, seharusnya guru menggunakan model atau benda nyata untuk topik-topik tertentu yang dapat membantu pemahaman siswa (Guntoro, 2010), Dengan demikian, jelas bahwa alat peraga dalam pembelajaran matematika sangat diperlukan

Proses pembelajaran menggunakan alat peraga berarti memaksimalkan fungsi seluruh pancaindra siswa untuk meningkatkan efektivitas belajar dengan cara melihat, mendengar, mempraktikkan, dan menggunakan pikirannya secara logis dan real.. Alat peraga dalam pembelajaran memegang peranan penting sebagai alat bantu yang efektif.

Alat peraga papan berpaku, yang dikenal dengan geoboard dibuat dari papan berbentuk persegi panjang atau persegi.pada papan itu dibuat persegipersegi kecil yang pada setiap titik sudutnya ditancapkan paku setengah masuk dan setengahnya masih timbul. Dalam hal ini ditambahkan karet gelang untuk membuat bangun datar pada papan berpaku tersebut.

Manfaat alat peraga geoboard dalam pembelajaran, siswa dapat lebih mudah dalam membuat bentuk geometri bangun datar segiempat tanpa memerlukan banyak waktu untuk menggambar di kertas dengan pensil dan penghapus, misalnya membuat persegi, persegi panjang, jajargenjang, trapesium, layang-layang dan belah ketupat. Dengan papan berpaku dapat dengan mudah menghitung keliling dan luas bangun datar segiempat.
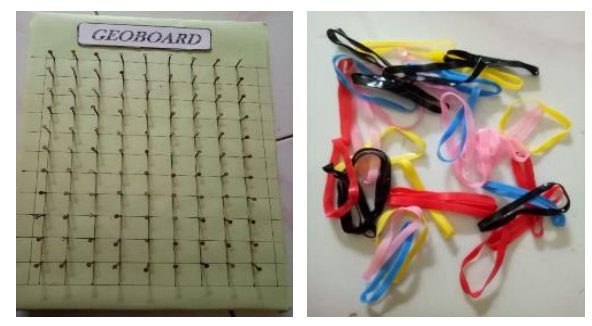

Gambar 1. Papan berpaku (geoboard) dan karet gelang

Pembelajaran pada dasarnya merupakan upaya mengarahkan siswa ke dalam proses belajar, sehingga mereka dapat memperoleh tujuan belajar sesuai dengan yang diharapkan. Implikasinya bahwa pembelajaran sebagai suatu proses yang harus dirancang, dikembangkan dan dikelola secara kreatif, dinamis, dengan menerapkan pendekatan bervariasi untuk menciptakan suasana dan proses pembelajaran yang kondusif bagi siswa (Syaifudin, 2014). Setiap konsep atau prinsip matematika dapat dimengerti secara sempurna hanya jika pertamatama disajikan kepada siswa dalam bentuk-bentuk nyata. Dengan demikian, dapat dikatakan bahwa betapa pentingnya manipulasi obyek-obyek/ alat peraga dalam bentuk permainan dalam pembelajaran.

Geoboard (papan berpaku) merupakan pengembangan dari media display atau sering dikenal dengan papan peragaan dan termasuk ke dalam jenis media visual diam yang mengandalkan indra penglihatan. (Dolhasair, 2017)

Alat peraga geoboard (papan berpaku) ini cocok untuk membantu 
siswa SMP dalam berbagai macam bentuk bangun datar, sehingga siswa akan lebih memahami bangun datar secara nyata, yang selama ini kebanyakan siswa hanya menghitung menggunakan dengan menghafal rumus. Selain itu, alat peraga geoboard dapat dikatakan sebagai sebuah permainan yang menyenangkan dan penuh tantangan, dimana siswa aktif terlibat dalam menuangkan kreativitasnya secara nyata dalam aspek imajinasi penemuan geometri. Alat peraga ini dapat digunakan secara klasikal maupun kelompok.

Agar pelaksanaan pembelajaran berjalan dengan baik dan hasilnya dapat diandalkan, maka perbaikan pembelajaran dapat diarahkan pada pengelolaan proses pembelajaran. Hasil belajar merupakan hal yang dapat dipandang dari dua sisi yaitu siswa dan guru. Dari sisi siswa, hasil belajar merupakan tingkat perkembangan mental yang lebih baik bila dibandingkan pada saat sebelum belajar, tingkat perkembangan mental tersebut terwujud pada jenis ranah kognitif, afektif dan psikomotor. Sedangkan dari sisi guru, hasil belajar merupakan saat terselesaikannya bahan pelajaran.

Adapun analisis dan pembahasan dalam penelitian ini berdasarkan tahapan untuk masing-masing siklus. Pada setiap siklus akan menjelaskan peningkatan pada aspek aktivitas belajar dan aspek hasil belajar, seperti pada uraian sebagai berikut:

\section{Siklus I}

Pada aspek aktivitas siswa dalam proses pembelajaran, mencakup tujuh indikator yang masing-masing indikator tercapai dalam persentase. Indikator pertama dalam proses pembelajaran yaitu mengajukan pertanyaan pada guru rata-rata persentase dari pertemuan pertama dan pertemuan kedua adalah
46,88\%, siswa masih bingung dengan pembelajaran yang dilaksanakan dengan menggunakan alat peraga dan model ELPSA, yang menjawab pertanyaan $28,13 \%$, mengerjakan lembar kegiatan secara berkelompok menunjukkan $60,94 \%$, bekerja sama dengan teman 1 kelompok $81,25 \%$, bertukar pendapat antar teman dalam kelompok 64,06\%, membuat kesimpulan $31,25 \%$, dan mempresentasikan hasil diskusi maupun hasil latihan $26,56 \%$, sehingga rata-rata aktivitas siswa secara klasikal pada siklus I adalah 55,36\%.

Pada aspek hasil belajar dari 28 siswa yang mengikuti ulangan 11 siswa dinyatakan tuntas atau 39,29\% dan 17 siswa tidak tuntas dalam belajar yaitu $60,71 \%$. Berdasarkan hasil tersebut ada beberapa faktor yang mempengaruhi, misalnya kurang maksimalnya guru dalam membimbing kesulitan belajar siswa, siswa belum terbiasa menggunakan alat peraga dan berpikir untuk menurunkan rumus bangun datar berbentuk persegi dan persegi panjang, kurang waktu untuk membahas soal-soal latihan, sehingga yang tuntas dalam belajar masih kurang dari $50 \%$ dan ratarata kelas masih di bawah ketuntasan minimal. Siswa yang belum tuntas diberikan pembelajaran remedial mandiri dan latihan soal-soal yang berkaitan dengan persegi dan persegipanjang, sehingga pada pertemuan berikutnya sudah dapat menyesuaikan dengan yang sudah tuntas dalam belajarnya.

Hasil analisis data angket siswa pada penggunaan alat peraga geoboard pada siklus I, yang terdiri dari 8 indikator, yaitu Alat peraga geoboard menarik untuk belajar. Kegiatan belajar dengan alat peraga geoboard menyenangkan. Penggunaan alat peraga geoboard memudahkan pemahaman terhadap materi yang dipelajari. Alat peraga geoboard merangsang untuk menumbuhkan rasa ingin tahu tentang 
matematika. Alat peraga ini sesuai digunakan sebagai media pembelajaran pada materi bangun datar segiempat. Belajar kelompok dengan menggunakan alat peraga geoboard membuat bisa belajar saling memberi dan menerima gagasan dari teman lain. Alat peraga geoboard mudah dipelajari secara kelompok.

Secara keseluruhan alat peraga geoboard mudah dipahami sehingga terdapat 10 siswa $(35,71 \%)$ menyatakan sangat setuju belajar bangun datar persegi dan persegi panjang menggunakan alat peraga geoboard, 11 siswa $(39,29 \%)$ menyatakan setuju belajar bangun datar segiempat menggunakan alat peraga geoboard, dan 7 siswa (25\%) menyatakan kurang setuju,

Berdasarkan hasil angket siswa tersebut menunjukkan Matematika dalam pembelajaran di sekolah memiliki beberapa karakteristik, yaitu objek yang dipelajari abstrak, kebenarannya berdasarkan logika, pembelajarannya secara bertingkat dan berkelanjutan, ada keterkaitan antara materi yang satu dengan yang lainnya, menggunakan bahasa simbol dan diaplikasikan di bidang ilmu lain. Pembelajaran matematika konvensional dirasa sudah tidak mampu meningkatkan pemahaman konsep matematika siswa dikarenakan sifat abstrak yang dimiliki matematika membuat siswa merasa kesulitan dalam menangkap konsep matematika. Berdasarkan karakteristik yang dimiliki matematika, dibutuhkan pembelajaran yang efektif yang mampu menjelaskan sifat abstrak dari matematika (Ismah, 2016).

Untuk itu, pembiasaan
penggunaan alat peraga ini sangat diperlukan sekali dalam penanaman konsep matematika, khususnya kelas VII SMP yang masih sangat sulit menerima konsep yang abstrak.

\section{Siklus II}

Pada aspek aktivitas siswa dalam proses pembelajaran pada siklus II tercapai dalam persentase. Setiap indikator sudah mengalami peningkatan persentase keaktifan siswa. Indikator pertama dalam proses pembelajaran yaitu mengajukan pertanyaan pada guru rata-rata persentase dari siklus I 46,88\% menjadi $47,92 \%$, siswa sudah mulai kenal dengan pembelajaran yang dilaksanakan dengan menggunakan alat peraga dan model ELPSA, yang menjawab pertanyaan siklus I $28,13 \%$ menjadi $27,08 \%$ ini disebabkan siswa asyik dengan alat peraganya sehingga kurang fokus dengan pertanyaanpertanyaan yang diajukan guru, mengerjakan lembar kegiatan secara berkelompok pada siklus I menunjukkan $60,94 \%$ menjadi $66,67 \%$,siswa sudah mulai terlihat aktivitas secara kelompok, bekerja sama dengan teman satu kelompok dari $81,25 \%$ menjadi $84,38 \%$, bertukar pendapat antar teman dalam kelompok dari $64,06 \%$ menjadi $78,13 \%$, membuat kesimpulan dari $31,25 \%$ menjadi $58,33 \%$, dan mempresentasikan hasil diskusi maupun hasil latihan dari $26,56 \%$ menjadi $27,08 \%$, sehingga ratarata aktivitas siswa secara klasikal pada siklus I adalah 55,36\% menjadi 63,61\% pada siklus II.

Hasil pembelajaran diperoleh bahwa, siswa yang tuntas dalam belajar sebanyak 15 siswa atau $53,57 \%$ dan yang tidak tuntas 13 siswa atau $46,43 \%$. Kemudian rata-rata nilai yang diperoleh dari siklus II ini mengalami peningkatan yaitu 61,90. Walaupun nilai rata-rata meningkat tapi proses pembelajaran yang telah dilaksanakan masih ada kekurangan atau belum maksimal, sehingga masih ada siswa yang belum tuntas. Untuk siswa yang belum tuntas diberikan remedial secara individu dan diberikan tugas di luar jam pelajaran, yang diharapkan dapat menuntaskan 
materi sebelum melanjutkan ke materi berikutnya.

Hasil analisis data angket pada siklus II, Terdapat 14 siswa (50\%) menyatakan sangat setuju belajar bangun datar belah ketupat dan layang-layang menggunakan alat peraga geoboard, 13 siswa $(46,43 \%)$ menyatakan setuju belajar bangun datar segiempat menggunakan alat peraga geoboard, dan 1 siswa $(3,57 \%)$ menyatakan kurang setuju. Dari analisis tersebut sudah mengalami peningkatan siswa yang merespons pembelajaran bangun datar segiempat dengan menggunakan alat peraga geoboard, namun demikian masih ada siswa yang kurang setuju, karena tidak fokus dengan pembelajaran yang sedang berlangsung.

Namun demikian, aktivitas siswa merupakan kegiatan atau perilaku yang terjadi selama proses pembelajaran. Kegiatan-kegiatan yang dimaksud adalah kegiatan yang mengarah pada pembelajaran seperti bertanya, mengajukan pendapat, mengerjakan tugas-tugas, dapat menjawab pertanyaan guru dan bisa bekerjasama dengan peserta didik lain, serta bertanggungjawab terhadap tugas yang diberikan (Amalina, 2018).

Jadi aktivitas siswa terlihat pada proses pembelajaran dengan model ELPSA dan menggunakan alat peraga geoboard yang telah dirancang dan disiapkan.

\section{Siklus III}

Pada aspek aktivitas siswa dalam proses pembelajaran pada siklus III setiap indikator aktivitas yang dilaksanakan dalam sudah mengalami peningkatan yang luar biasa. Indikator pertama dalam proses pembelajaran yaitu mengajukan pertanyaan pada guru rata-rata persentase dari siklus II 47,92\% menjadi $67,75 \%$, dikarenakan siswa sudah mulai terbiasa dengan pembelajaran yang dilaksanakan dengan menggunakan alat peraga dan model ELPSA, yang menjawab pertanyaan siklus II $27,08 \%$ menjadi $34,38 \%$ ini disebabkan siswa sudah mulai terarah dengan alat peraganya sehingga mereka fokus dengan pertanyaan-pertanyaan yang diajukan guru, mengerjakan lembar kegiatan secara berkelompok pada siklus II $66,67 \%$ menjadi $73,44 \%$, siswa sudah mulai terlihat aktivitas secara kelompok, bekerja sama dengan teman satu kelompok dari $84,38 \%$ menjadi $87,50 \%$, bertukar pendapat antar teman dalam kelompok dari $78,13 \%$ menjadi $87,50 \%$, membuat kesimpulan dari $58,33 \%$ menjadi $73,44 \%$, dan mempresentasikan hasil diskusi maupun hasil latihan dari $27,08 \%$ menjadi $31,25 \%$, sehingga rata-rata aktivitas siswa secara klasikal pada siklus II adalah $63,61 \%$ menjadi $74,49 \%$ pada siklus III.

Pada aspek hasil belajar, siswa yang tuntas dalam belajar sebanyak 21 siswa atau $75 \%$ dan yang tidak tuntas 7 siswa atau $25 \%$. Kemudian rata-rata nilai yang diperoleh dari siklus III ini mengalami peningkatan yaitu 67,41. Peningkatan aktivitas belajar ternyata berefek pada hasil pembelajaran juga meningkat, walau masih ada siswa yang belum tuntas. Untuk siswa yang belum tuntas diberikan remedial secara individu dan diberikan tugas di luar jam pelajaran, yang diharapkan dapat menuntaskan materi sebelum melanjutkan pelaksanaan tes.

Ketuntasan belajar merupakan berhasilnya pembelajaran dengan model ELPSA dengan bantuan alat peraga geoboard pada materi bangun datar segiempat, karena penyampaian materi matematika dengan model ELPSA yang melibatkan pengalaman siswa, menggali bahasa siswa untuk memahami konsep dasar melalui alat peraga dapat 
meningkatkan minat dan hasil belajar (Dwijopitoyo, 2017)

Persentase ketuntasan dari siklus I ke siklus II naik $14,28 \%$ walaupun yang tuntas belum mencapai $75 \%$ dan ratarata nilai pada siklus I belum mencapai nilai Kriteria Ketuntasan Minimal (KKM) 60, tapi pada saat siklus II rataratanya mencapai 61,90 dan pada siklus III mencapai 67,41, mengalami kenaikan 5,51 .

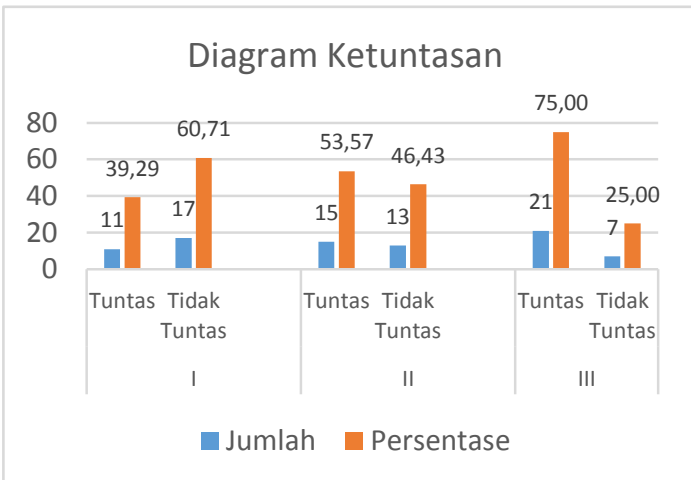

Gambar 2. Diagram Ketuntasan Belajar

Berdasarkan Gambar 2 tersebut menunjukkan bahwa pembelajaran menggunakan model ELPSA dengan bantuan alat peraga geoboard pada materi bangun datar segi empat sangat menarik minat siswa untuk belajar, sehingga dapat meningkatkan aktivitas belajar dan diiringi dengan meningkatnya hasil belajar yang ditunjukkan dengan ketuntasan $75 \%$.

Penelitian yang hampir serupa yang pernah dilakukan oleh (Masturoh, 2017) Alat peraga geoboard memiliki pengaruh terhadap hasil belajar siswa pada mata pelajaran matematika, dan dengan menggunakan alat peraga geoboard mempermudah siswa untuk mengetahui hasil keliling dan luas bangun datar dengan konkret dan terdapat unsur bermain dalam penggunaannya karena dapat digunakan untuk membentuk macam-macam bangun datar seperti jajar genjang dan segitiga dengan permainan karet gelang.
Geoboard (papan berpaku) merupakan pengembangan dari media display atau papan peragaan dan termasuk ke dalam jenis media visual diam yang mengandalkan indera penglihatan. Menurut (Munadi, 2013), media visual adalah media yang melibatkan indera penglihatan. Terdapat dua jenis pesan yang dibuat dalam visual, yakni pesan verbal dan non verbal . pesan verbal terdiri atas katakata (bahasa verbal) dalam bentuk tulisan dan pesan nonverbal adalah pesan yang dituangkan dalam bentuk simbol.

\section{KESIMPULAN DAN SARAN}

Dari hasil dan pembahasan di atas menunjukkan, bahwa penggunaan model ELPSA dengan bantuan alat peraga geoboard dalam materi bangun datar segiempat (persegi, persegipanjang, jajargenjang, trapesium, belahketupat, layang-layang) dapat meningkatkan aktivitas siswa dalam proses pembelajaran dengan indikator mengajukan pertanyaan pada guru, menjawab pertanyaan dari guru, mengerjakan LKS yang diberikan, bekerja sama dengan teman satu kelompok, bertukar pendapat antar teman satu kelompok, membuat kesimpulan hasil diskusi, mempresentasikan hasil diskusi. Sedangkan pada aspek hasil belajar menunjukkan adanya peningkatan hasil belajar siswa dari siklus ke siklus yang ditunjukkan dengan :

a) Terjadi peningkatan aktivitas dari rata-rata $55,36 \%$ pada siklus I, menjadi $63,61 \%$ pada siklus II dan meningkat menjadi $74,49 \%$ pada siklus III. b) Terjadi peningkatan rata-rata hasil belajar siswa dari 55,06 pada siklus I, menjadi 61,90 pada siklus II dan meningkat menjadi 67,41 pada siklus III.Selain aktivitas dan hasil belajar siswa dalam proses pembelajaran 
menggunakan model ELPSA dengan bantuan alat peraga geoboard pada materi bangun datar segiempat, berdasarkan angket menunjukkan persentase siswa yang menyatakan sangat setuju $35,71 \%$ pada siklus I, $35,71 \%$ pada siklus II dan naik menjadi $50,00 \%$ pada siklus III, kemudian yang menyatakan setuju 39,29\% pada siklus I, menjadi $53,57 \%$ pada siklus II dan meningkat lagi menjadi $46,43 \%$ pada siklus III.

Berdasarkan kesimpulan di atas, maka saran yang dapat diberikan adalah, bahwa penggunaan model ELPSA dengan bantuan alat peraga geoboard dalam pembelajaran matematika mampu mengaktifkan siswa belajar yang bermakna, yang dapat meningkatkan aktivitas dan hasil belajar matematika siswa.

\section{DAFTAR PUSTAKA}

Amalina. (2018). Keefektifan Penerapan Pendekatan ELPSA dengan setting kooperatif dalam Pembelajaran matematika materi sistem Koordinat Kartesius pada kelas VIII SMPN 2 Kab. pangkep. e-prints. Diakses September 27, 2018, dari http://eprints.unm.ac.id/6869/

Arsyad, A. (2011). Media Pembelajaran. Jakarta: PT Raja Grafindo Persada.

Astuti. (2011). Penyusunan proposal PTK dalam Pembelajaran Matematika SMP. Yogyakarta: P4TK Matematika.

Dolhasair, G. (2017). Penggunaan Media Geoborad untuk meningkatkan Pemahaman Konsep bangun datar Pada Siswa Sekolah Dasar. Didaktika Dwija Indria, Volume 5 No. 3. Diakses September 27, 2018

Dwijopitoyo, B. F. (2017). Meningkatkan Minat Belajar Siswa Terhadap Pelajaran Matematika SMP Menggunakan Kerangka
Pembelajaran ELPSA. Prosiding Seminar ELPSA. Mataram NTB: IKIP Mataram.

Effendi, L. A. (2012). Pembelajaran matematika dengan metode Penemuan Terbimbing untuk meningkatkan kemampuan representatif dan Pemecahan masalah matematis siswa SMP. Jurnal Penelitian Pendidikan UPI, Vol. 13 No.2.

Guntoro, T. W. (2010). Penggunaan Alat Peraga dalam Pembelajaran Matematika SMP. Yogyakarta: P4TK Matematika.

Hartati. (2010). Pengembangan Alat peraga gaya Gesek untuk meningkatkan Ketrampilan berpikir Kritis Siswa SMA. JPFI, volume 6 No. 2. Diakses September 4, 2018

Ikasari, J. (2017). Identifikasi bentuk Partisipasi Siswa SMP dalam Pembelajaran Matematika berbasis ELPSA. JMPM, volume 5 No. 2. Diakses September 27, 2018, dari http://ojs.ikipmataram.ac.id/index.p hp/jmpm/user/register

Imas, M. d. (2017). Pengaruh penggunaan alat peraga Geoboard terhadap. Banten: IAIN Sultan Maulana Hasanudin. Diambil kembali dari http://repository.uinbanten.ac.id/637

Ismah. (2016, Desember). Perbandingan tingkat Pemahaman Konsep matematika Siswa melali media interaktif Mischief dan konvensional. Jurnal Teknodik, 20 No. 2.

Johar, H. d. (2016). Implementation of ELPSA Framework in Teaching Integral. International Journal of Science and Applied Technology, Vol. 1, No. 1, December 2016. Diakses September 4, 2018, dari http://IJSAT.unri.ac.id/

Kadir, K. (2018). Penerapan langkahlangkah Pembelajaran Van Hiele 
DOI: https://doi.org/10.24127/ajpm.v8i1.1767

$$
\begin{aligned}
& \begin{array}{l}
\text { Berbantuan Media manipulatif } \\
\text { geoboard }
\end{array} \text { sebagai } r \text { upaya } \\
& \text { meningkatkan } \\
& \text { segiempat siswa. Jurnal Pendidikan } \\
& \text { UNM. }
\end{aligned}
$$

Laila, F. (2010). Pengaruh Model Pembelajaran Cooperative Tipe Group Investigation (Gi) Dan Stad Terhadap Prestasi Belajar Matematika Ditinjau Dari Kemandirian Belajar Siswa. Universitas Sebelas maret. Diakses September 27, 2018, dari https://eprints.uns.ac.id/id/eprint/862 1

Masturoh, I. (2017). Pengaruh Penggunaan Alat Peraga Geoboard terhadap Hasil Belajar pada Pokok Bahasan Geometri. Primary, Volume 9 No. 02. Diakses September 27, 2018

Mujiono, D. d. (2009, 08). Diakses 3 21, 2015, dari http://tips-belajarinternet.blogspot.com.

Munadi, Y. (2013). Media Pembelajaran; Sebuah Pendekatan baru. jakarta: GP Press Group.

Patahudin, T. L. (2015). ELPSA As a Lesson Design Framework. IndoMS-JME, Volume 6, No. 2, pp.1-15.

Patahudin, T. L. (2015). ELPSA- Kerangka Kerja untuk Merancang Pembelajaran Matematika. Jurnal didaktik Matematika. Diambil kembali dari http://www.jurnal.unsyiah.ac.id/DM /article/view/2390/2256

Supinah. (2015). Aktifitas Siswa. Diakses Agustus 21, 2018, dari http://p4tkmatematika.org.

Suprijono. (2010). Cooperative Learning. Jakarta: CTSD.

Syaifudin. (2014). Inovasi Pendidikan. Bandung: Alfabeta.

Widiyasari, R. (2017). Meningkatkan aktivitas dan hasil Belajar
Mahasiswa menggunakan MIND

MAP Berbantuan E.Learning. Jurnal Teknodik, Volume 21, No. 1. Diakses September 8, 2018

Wijaya. (2014). Pengenalan Desain Pembelajaran ELPSA. 